\title{
Marketing analysed of Kampung Chicken on the Traditional Market of Binjai City
}

\author{
J B Sitanggang, A H Daulay, T H Wahyuni, I Sembiring, M Tafsin \\ Animal Production Program Study, Faculty of Agriculture, University of North \\ Sumatera, Medan 20155, Indonesia \\ Email: sitanggangjun23@gmail.com
}

\begin{abstract}
Absract. This study aims to identify the characteristics of farmers, agents and retailers of kampung chicken marketing, and kampung chicken marketing channels, marketing margins, farmer share, profit ratio, and cost of kampung chicken, as well as analysed the marketing efficiency of kampung chicken in Binjai City. This research was conducted in June 2018 August 2018. The method used in data collection by using the Jenuh sampling (sensus), while the sample of breeders and other marketing institutions with search method. Data collection was carried out using interview questionnaire techniques.

Data analysis included marketing costs, marketing margins, farmer share and cost benefit ratio of each marketing channel. The results of this study indicate that there are two marketing channels. The marketing margin on channel II shows margin Rp. 15.157,-. the farmer's in channel I 76.19\% and ratio of profit Rp. 2.4 per $\mathrm{kg}$ on channel II. The marketing channel for kampung chicken in the Traditional Market of Binjai City is efficient.
\end{abstract}

\section{Introduction}

The average production of kampung chickens per capita per year in Binjai City in 2015 was 33,480 tons and in 2016 there were 21,180 tons [1].

Community demand for kampung chickens can be said good because many people in Indonesia have begun to become aware of nutrition. Kampung chicken has high nutritional value with delicious taste and is accepted by all religious groups for religious holidays and various people's parties [2].

Increasing population growth in line with higher levels of education causing public awareness of the importance of animal protein getting higher

and the demand for livestock products from year to year is increasing [3].

\section{Research and Methods}

\subsection{Time and place of research}

This research was conducted in the traditional market of Binjai City, North Sumatra province. This research was conducted from July to August 2018.

\subsection{Methods}

The method used in this study is the census method with retailers who sell kampung chicken in traditional markets, while the collectors and breeders are determined by search method by following the marketing flow based on information obtained from previous kampung chicken retailers. 


\subsection{Methods for determining research areas}

The research location was determined purposively (intentionally) in several traditional markets in the Binjai City. The traditional markets chosen as research locations are Tavip Market in Binjai Kota Subdistrict, Kampung Lada Market in Binjai Utara Subdistrict, and Brahrang Market in Binjai Barat Subdistrict. The reason for choosing these three traditional markets is the research location because the three traditional markets sell the commodities to be studied and are a large market in the Binjai City.

\subsection{Method of collecting data}

Data collection conducted in this study, namely:

Observation, collecting through systematic observation and recording.

The interview was conducted by asking questions face to face with the respondents by filling out the questionnaire. Questionnaire is a number of questions submitted to respondents to obtain primary. Literature study, carried out by studying and retrieving data from literature and other sources that are considered able to provide information about this research such as books, previous research, journals and the internet.

\subsection{Analysis data}

The data obtained in this study are processed qualitatively and quantitatively, and are presented in the form of a description and tabulation of numbers. Data processing is done by descriptive method.

Marketing margin is formulated by calculating the difference between the price at the consumer level and the price at the producer level. According to Soekartawi [4], marketing margins are formulated as follows:

$$
\mathrm{Mp}=\mathrm{Pr}-\mathrm{Pf}
$$

Information:

MP: Marketing margin $(\mathrm{Rp} / \mathrm{Kg})$

Pr: Price at the consumer level $(\mathrm{Rp} / \mathrm{Kg})$

Pf: Prices at farmer level $(\mathrm{Rp} / \mathrm{Kg})$

Analysis of Farmer's Share received by the manufacturer. To calculate the farmer's share (the portion received by the farmer) according to Sudiyono [5] the formula is used:

$$
\mathrm{Fs}=\frac{\mathrm{Pf}}{\operatorname{Pr}} \times 100 \%
$$

Information :

Fs: Farmer's Share (\%)

Pr: Price at the consumer level $(\mathrm{Rp} / \mathrm{Kg})$

Pf: Prices at farmer level $(\mathrm{Rp} / \mathrm{Kg})$ 
Rasio Keuntungan terhadap Biaya $=$ Total Keuntungan $/$ Biaya Pemasaran

Marketing Efficiency

$$
\text { Efisiensi Pemasaran }=\frac{\text { Total Biaya Pemasaran }}{\text { Total Harga Produk }} 100 \%
$$

According to Rosmawati [6] that marketing systems are said to be efficient if the value of marketing efficiency is $0-33 \%$.

The benchmark used to measure marketing efficiency is to look at a comparison of the profit share of each marketing agency involved in the marketing process compared to the marketing costs of each marketing institution involved with the following criteria:

1. Marketing margins

Marketing is said to be efficient if the farmer's marketing margin is greater than the marketing margin received by the marketing agency as a whole and vice versa.

2. Based on farmer's share

It's said to be efficient if farmer's share is $>50 \%$. The farmer's share has a negative relationship with marketing margins, which means that the higher the marketing margin, the lower the farmer's share.

3. Cost benefit ratio

It is said to be efficient if the cost benefit ratio is> 1 and vice versa

\section{Results and Discussion}

\subsection{Marketing channel}

In marketing activities there are marketing institutions that are intermediary institutions that connect producers to consumers in delivering production results:

Marketing channel I

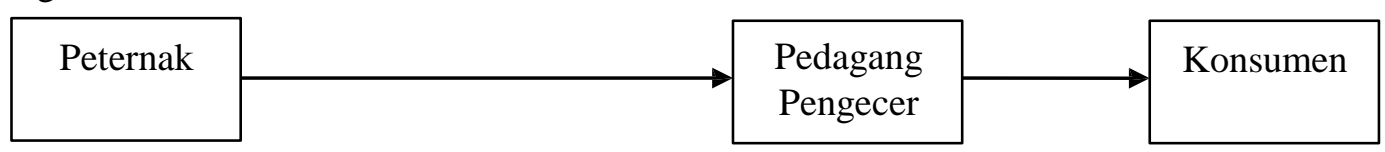

Figure 1. Marketing Channel I

Based on the picture above is the type of marketing which includes a one-level marketing channel because this channel only uses one intermediary institution, namely retailers. Raised chicken breeders on this channel come from Binjai City and taken directly by retailers on the market using motorbike.

Marketing channel II

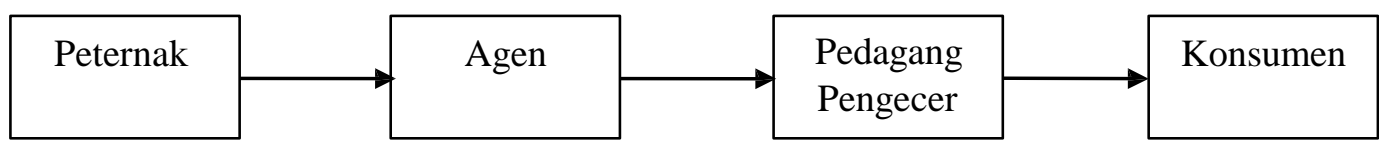

Figure 2. Marketing Channel II 
Based on the picture above, the second marketing channel is a two-level marketing channel because of the marketing of kampung chickens from farmers to consumers through 2 marketing institutions, namely traders or agents and retailers. Breeders come from inside and outside Binjai City and sell kampung chickens to agents who come to farmers. Agents transport kampung chickens motorbikes and sell them directly to retailers on the market.

\subsection{Marketing Margin}

The biggest marketing margin is in the marketing channel II, which is Rp. 15.157 because lane II is the longest chain of marketing lanes, this is because in the marketing lane II there are differences in higher selling prices from agents to retailers.

The smallest marketing margin is in the marketing channel I, which is Rp. 12.500 where in this path the farmer sells kampung chickens directly to the retailer. In addition, retailers only sell kampung chickens in small quantities. On lines I and II, the marketing margin is determined by the distribution distance and the short length of the marketing.

In both marketing routes for kampung chickens, the biggest cost is borne by the marketing path I, which is Rp. 4.625 per $\mathrm{kg}$. This is because because lane I is the shortest marketing chain and only sell kampung chickens in small quantities. While the smallest costs are in marketing II, while the costs borne by the marketing channel II are Rp. 4.450 which is the longest marketing chain.

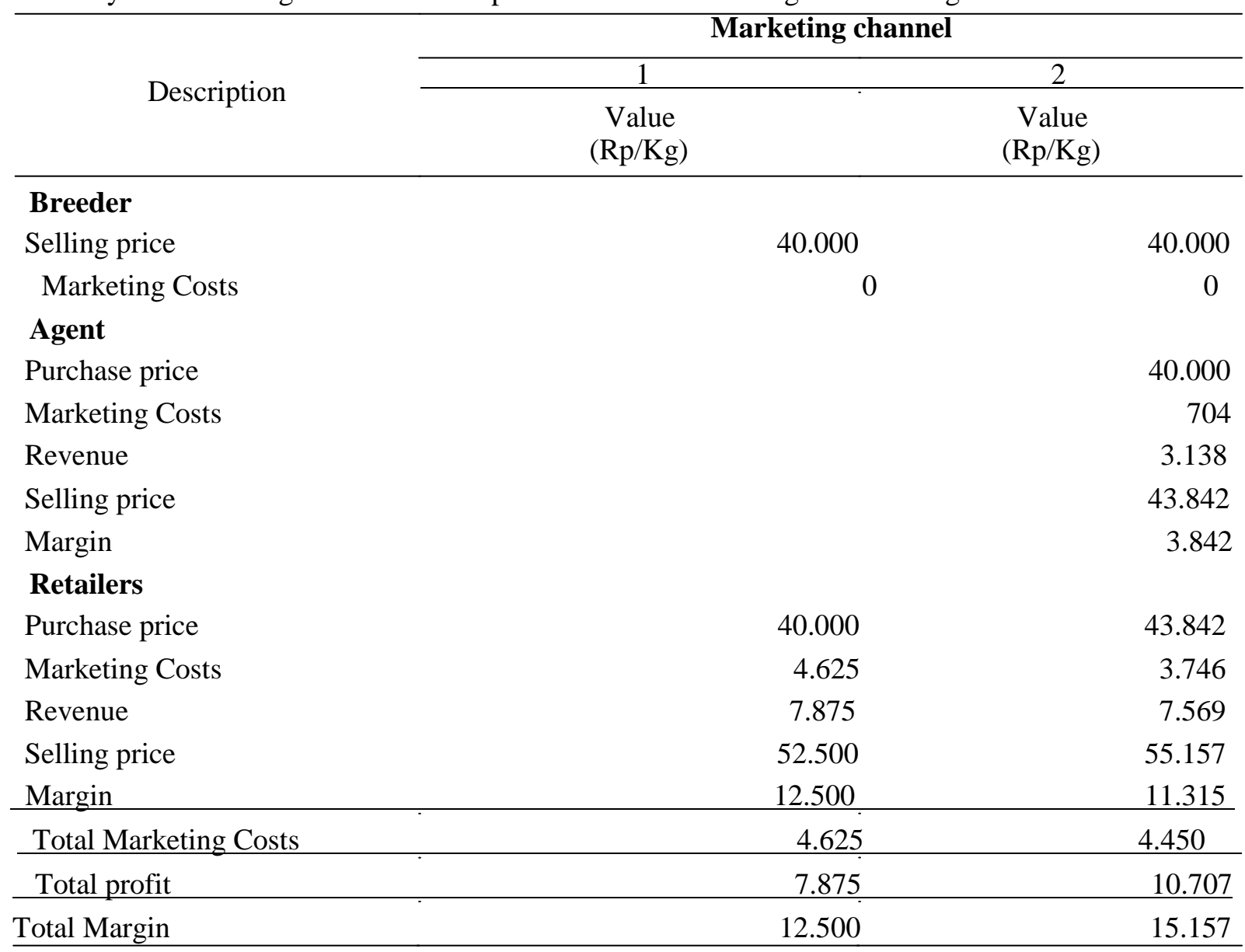


The biggest marketing advantage is in the marketing channel II, which is Rp. 10.707 because it is the longest marketing chain and consumers who buy most of the kampung chickens are sold in large quantities. The smallest profit is in the marketing channel I, which is Rp. 7.875, this is because there are only a few kampung chickens distributed in this line.

\subsection{Farmer's Share}

$\begin{array}{cccc}\text { Marketing channel } & \begin{array}{c}\text { Prices at the Farmer } \\ \text { Level }(\mathrm{Rp} / \mathrm{Kg})\end{array} & \begin{array}{c}\text { Price at the Consumer Level } \\ (\mathrm{Rp} / \mathrm{Kg})\end{array} & \begin{array}{c}\text { Farmer's Share } \\ (\%)\end{array}\end{array}$

\begin{tabular}{llll}
\hline I & 40.000 & 52.500 & 76,19 \\
II & 40.000 & 55.157 & 72,52 \\
\hline
\end{tabular}

Farmer 's share is a comparison between prices received by farmers and prices paid by consumers, and is generally expressed as a percentage. Farmer's share is inversely related to marketing margins, meaning that the higher the marketing margin, the lower the farmer's share.

Farmer's highest share on marketing channel I is $76,19 \%$, meaning that farmers receive a price of $76,19 \%$ of the price paid by consumers. In addition, the marketing channel II obtained the lowest farmer share value of $72,52 \%$.

\subsection{Profit and Cost Ratio}

Marketing costs are costs incurred by marketing agencies in distributing kampung chickens from breeders to end consumers expressed in rupiah per $\mathrm{kg}$. While the benefits of marketing institutions are the difference between marketing margins and costs incurred during the marketing process. Costbenefit ratio analysis per cost can be used to determine whether the marketing activities carried out provide benefits to the marketing actors.

In channel I the total cost incurred by retailers is $\mathrm{Rp} .4 .625$ per kg while profits are Rp. 7.875 per $\mathrm{kg}$. Then the cost benefit ratio is Rp. 1,7 per kg.

In channel II the total cost spent per egg is $\mathrm{Rp}$. 4.450. The biggest cost is borne by the retailer, amounting to Rp. 3.746 per $\mathrm{kg}$, the lowest marketing cost borne by the agent is Rp. 704 per $\mathrm{kg}$. The biggest advantage obtained by the retailer is $\mathrm{Rp} .7 .569$ per $\mathrm{kg}$, while the lowest profit is obtained by retailers, namely Rp. 3.138 per $\mathrm{kg}$. Then the cost benefit ratio is Rp. 2,4 per $\mathrm{kg}$.

\begin{tabular}{lrrr}
\multicolumn{1}{c}{ Marketing Institute } & $\begin{array}{c}\text { Profit } \\
\text { (Rp/Item) }\end{array}$ & $\begin{array}{c}\text { Cost } \\
\text { (Rp/Item) }\end{array}$ & $\pi / \mathrm{C}$ \\
\hline Channel I & & & \\
Retailers & 7.875 & 4.625 & 1,7 \\
\hline Total & 7.875 & 4.625 & 1,7 \\
\hline Channel II & & & 4,5 \\
Agent & 3.138 & 704 & 2,02 \\
Retailers & 7.569 & 3.746 & 2,4 \\
\hline Total & 10.707 & 4.450 & \\
\hline
\end{tabular}




\subsection{Marketing Efficiency}

Based on the formula of Rosmawati (2011) the marketing system can be said to be efficient if the value of marketing efficiency is $0-33 \%$, by looking at the results of analysis in table 23 , that the efficiency of all marketing institutions involved in marketing kampung chickens in traditional markets in the Binjai City is $0-33 \%$ which means efficient.

\begin{tabular}{lcrrr}
\hline \multicolumn{1}{c}{ Marketing Institute } & $\begin{array}{c}\text { Cost } \\
(\mathrm{Rp} / \mathrm{kg})\end{array}$ & $\begin{array}{c}\text { Product Value } \\
(\mathrm{Rp} / \mathrm{kg})\end{array}$ & \multicolumn{2}{c}{$\begin{array}{c}\text { Efficiency Value } \\
(\mathrm{Rp} / \mathrm{kg})\end{array}$} \\
\hline Channel I & & & & 8,8 \\
Retailers & 4.625 & 52.500 & \\
Channel II & & & 1,6 \\
Agent & 704 & 43.842 & 6,7 \\
Retailers & 3.746 & 55.157 & \\
\hline
\end{tabular}

\section{Conclusions}

Marketing kampung chicken in the traditional market of Binjai City consists of 2 marketing channels, namely marketing channels involving one marketing agency and marketing channel involving two marketing institutions. The marketing institutions involved are farmers as kampung chicken producers, agents or collectors, and retailers.

Data analysis includes marketing costs, marketing margins, farmer share and cost benefit ratio of each marketing channel. The marketing margin on channel II shows margin Rp. 15.157,-. the farmer's in channel I 76.19\% and ratio of profit Rp. 2.4 per $\mathrm{kg}$ on channel II. The marketing channel for kampung chicken in the traditional market of Binjai City is efficient.

\section{References:}

[1] Badan Pusat Statistik. 2016. Kota Binjai Dalam Angka. Badan Pusat Statistik Kota Binjai.

[2] Cahyono, B. 1998. Ayam Buras Pedaging. Penerbit Trubus Agriwidya, Jakarta.

[3] Hasibuan, E, N. 2016. Pemanfaatan Teung Biji Durian Sebagai Pengganti Tepung Jagung dalam Ransum Terhadap Karkas Ayam Kampung. Skripsi. Program Studi Peternakan Universitas Sumatera Utara, Medan.

[4] Soekartawi. 1989. Prinsip Dasar Ekonomi Pertanian. Teori dan Aplikasinya. Penerbit Rajawali. Jakarta.

[5] Sudiyono, A. 2002. Pemasaran Pertanian. Muhammadiyah University Press. Malang.

[6] Rosmawati, H. 2011. Analisis Efisiensi Pemasaran Pisang Produksi Petani di Kecamatan Lengkiti Kabupaten Ogan Komering Ulu. Jurnal Agronobis. Vol.3 (5) : 19. 